\title{
Ten-year neonatal hepatitis B vaccination program, the Netherlands, 1982-1992: protective efficacy and long-term immunogenicity
}

\author{
R. del Canho*, P.M. Grosheide*, J.A. Mazel†, R.A. Heijtink $\ddagger$, W.C.J. Hop§, \\ L.J. Gerards $\|$, G.C. de Gast I, W.P.F. Fetter ${ }^{\star}$, J. Zwijneberg ${ }^{\mathrm{a}}$ and \\ S.W. Schalm*b
}

From 1982 to 1989, 705 infants born to HBsAg-positive mothers entered the Dutch neonatal hepatitis $B$ vaccination program and received passive-active hepatitis $B$ immunization in three randomized controlled trials testing variations in time of starting active vaccination, dose and type of vaccine, and number of hepatitis $B$ immunoglobulin (HBIg) injections. A meta-analysis of individual patient data of the three randomized trials was performed to determine which independent host and vaccination related factors influence protective efficacy and long-term immunogenicity, and to assess whether hepatitis $B$ vaccination concomitant with standard DKTP vaccination provides optimal protection. Statistical methodology included multivariate logistic regression analysis. Eight infants (1.1\%), all born to HBeAg-positive mothers, became $H B s A g$ carriers within the first year of life. The protective efficacy rate (PER) of passive-active immunization at 12 months follow-up was $92 \%$ for the total group of children from $114 \mathrm{HBeAg}$-positive mothers with no significant differences between children starting active immunization at birth or at 3 months of age, between infants starting at 3 months of age receiving one or two doses of HBIg or between those receiving plasma derived or recombinant vaccine. The only factor that affected the PER significantly was the level of maternal HBV DNA; PER was $100 \%$ if maternal $H B V D N A$ was $<150 \mathrm{pg} \mathrm{ml} l^{-1}$ and $68 \%$ for HBV DNA levels $>150 \mathrm{pg} \mathrm{ml}^{-1}$. After 5 years of follow-up, the group that started active immunization at birth had significantly more infants with loss of seroprotection (anti-HBs levels $<10 \mathrm{IU} l^{-1}, 15 \%$ ) than the corresponding group starting at 3 months of age (anti-HBs $<10 \mathrm{IUl}^{-2}, 2 \%$ ). One of 35 children with loss of seroprotection at 2 years became a HBsAg carrier in the fifth year of follow-up. This meta-analysis shows that the protective efficacy of passiveactive hepatitis $B$ vaccination is mainly influenced by material HBV DNA levels, and independent of the time of starting active vaccination at birth or at 3 months of age; long-term immunity was enhanced by starting active vaccination concomitant with $D K T P$ vaccination. These findings allow incorporation of hepatitis $B$ vaccine into the standard infant immunization programs for countries with a passive-active immunization strategy for the control of hepatitis $B$. Additional measures are needed to protect neonates of highly viremic women. (C) 1997 Elsevier Science Ltd.

Keywords: hepatitis B, vaccine plasma, hepatitis B immunoglobulin, recombinant, neonates. meta-analysis. randomized conrolled trials.

\footnotetext{
*Department of Internal Medicine II, University Hospital Dijkzigt, Rotterdam, Netherlands, and the Dutch study group Prevention Neonatal Hepatitis B.†General Practice, Borne, Netherlands. †़Department of Virology, Erasmus University, Rotterdam, Netherlands. §Department of Epidemiology and Biostatistics, Erasmus University, Rotterdam, Netherlands. Wilhelmina Children's Hospital, University Hospital Utrecht, Utrecht, Netherlands. IDepartment of Hematology, University

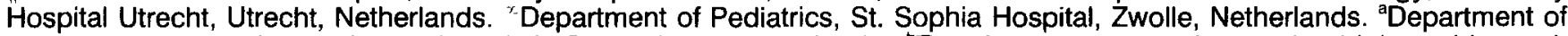
Pediatrics, Ruwaard van Putten Hospital, Spijkenisse, Netherlands. 'To whom correspondence should be addressed. Department of Hepatogastroenterology (section Hepatology), University Hospital Dijkzigt, Dr. Molewaterplein 40, 3015 GD Rotterdam, Netherlands. Tel.: 31-10-4635942; fax: 31-10-4365961. (Received 24 July 1996; revised version received 12 February 1997; accepted 4 March 1997)
} 
When hepatitis B vaccine was licensed in the Netherlands in 1982, a program was started to screen mothers for $\mathrm{HBs} A g$ positivity and to immunize their offspring. In the first randomized trial a passive-active immunization schedule starting at birth was compared with a schedule with active immunization starting at 3 months of age, concomitant with diphtheria-tetanus-pertussis and poliomyelitis (DTPP) vaccination. The authors hypothesized that efficacy of delayed active immunization would be similar, but long-term immunogenicity superior to immunization starting at birth. Such a result would allow incorporation of active hepatitis B immunization in the standard infant immunization program, which was thought to be advantageous with respect to logistics and costs. Our preliminary results supported this hypothesis ${ }^{1.2}$. In 1984 a second randomized trial was started to compare the short- and longterm immunogenicity of the standard vaccine dose with a pediatric dose. With the introduction of recombinant vaccine in 1987, a third randomized trial was performed to confirm the efficacy of delayed vaccination with the recombinant vaccine; this trial also allowed testing the need for supplementary hepatitis B immunoglobulins ( $\mathrm{HBIg})$ at the start of delayed active immunization ${ }^{3}$.

Our recent finding ${ }^{4}$, also observed by others ${ }^{5-7}$, that vaccination failure is also related to high maternal HBV DNA levels made it necessary to re-evaluate the effects of the components of the various schedules: time of starting active immunization, types and doses of vaccine and $\mathrm{HBIg}$ used, in relation to maternal HBV DNA levels.

This final report of the Dutch program for prevention of perinatal hepatitis $B$ describes the protective efficacy and long-term immunogenicity of passiveactive hepatitis B immunization over a period of 10 years.

\section{SUBJECTS AND METHODS}

\section{Hepatitis B screening}

The study was started in July 1982 in three large city hospitals in Rotterdam and Utrecht and one large rural area, Twente-Gelderse Achterhoek. Blood samples obtained from all pregnant women at their first visit to the prenatal clinic of the participating centers were tested for the presence of $\mathrm{HBsAg}$. If $\mathrm{HBs} \mathrm{Ag}$ positivity was confirmed, randomization to one of the immunization schedules took place after informed consent was obtained from the mother. In the two participating hospitals in Rotterdam, the HBsAg status of expectant mothers was checked soon after arrival in the delivery room. Whenever prenatal $\mathrm{HBsAg}$ test results were missing, blood was obtaincd and tested the next morning with a rapid hemagglutination $\mathrm{HBsAg}$ test. If the rapid $\mathrm{HBs} A \mathrm{~g}$ test was positive, the mother was asked for informed consent and the baby was randomized and included in the immunization trial. All pregnant $\mathrm{HBs} \mathrm{Ag}$-positive women were also tested for the presence of $\mathrm{HBeAg}$. In December 1992, maternal HBV DNA levels were quantified retrospectively in the available stored serum samples positive for $\mathrm{HBeAg}$.

\section{Subjects and immunization schedules}

From July 1982 to March 1984, 238 eligible babies were randomly allocated to one of the two initial plasma vaccine immunization schedules (Table 1 , groups 1-II); from April 1984 to December 1987, 257 babies entered the plasma vaccine immunogenicity study (Table I, groups III-IV); from January 1988 to October 1989, another 210 eligible babies were allocated to one of the two recombinant vaccine immunization schedules (Table I, groups V-VI).

All infants received $\mathrm{HBIg}(200-300) \mathrm{IU}$, Central Laboratory of the Netherlands Red Cross Blood Transfusion Service, Amsterdam) i.m. within $2 \mathrm{~h}$ of birth by the physician or midwife in charge of the delivery. For active immunization, infants were referred to a pediatrician. Infants received plasma vaccine (10) and $5 \mu \mathrm{g}$ HBvax, Merck Sharp \& Dohme, West Point, USA) or recombinant vaccine $(20 \mu \mathrm{g}$ Engerix-B, SmithKline Beecham, Rixensart, Belgium). Nine infants (one in group II, three in group III and five in group IV) with an anti-HBs level $\leq 10 \mathrm{lU} \mathrm{I}^{\prime}$ at 12 months of age and a negative test for $\mathrm{HBsAg}$ received an additional course of plasma vaccine or recombinant vaccine in their second year of life.

\section{Serological assays and laboratory methods}

Blood samples were taken from the infants at birth (cord blood) and in groups I and II at months 3, 6, 11, 12 and then yearly until 9 years of age; in groups III and IV at months $3,6,12$ and then yearly until 5 years of age; in groups $\mathrm{V}$ and $\mathrm{VI}$ at months $3,4,6,11,12$ and at 2 years of age. All serum samples were tested for anti-HBs and anti-HBc; HBsAg was assayed in all samples with anti-HBs below 100 IU I!

Table 1 Immunization schedules of study groups

\begin{tabular}{|c|c|c|c|c|c|c|c|}
\hline \multirow[b]{2}{*}{ Group } & \multirow[b]{2}{*}{ Entry period } & \multicolumn{3}{|c|}{ No. of infants } & \multirow{2}{*}{$\begin{array}{l}\frac{\mathrm{HBlg}}{\mathrm{a}} \\
\begin{array}{l}\text { Months/ } \\
\text { dose after birth }\end{array}\end{array}$} & \multirow{2}{*}{$\begin{array}{r}\text { Vaccine } \\
\text { Type/dose }\end{array}$} & \multirow{2}{*}{$\begin{array}{l}\text { Schedule } \\
\begin{array}{l}\text { Months atter } \\
\text { birth }\end{array}\end{array}$} \\
\hline & & $\begin{array}{l}\text { Total } \\
\text { (mother } \mathrm{HBeAg}+\text { ) }\end{array}$ & $\begin{array}{l}\text { Evaluated for } \\
\text { immunogenicity }\end{array}$ & $\begin{array}{l}\text { Evaluated for } \\
\text { efficacy }\end{array}$ & & & \\
\hline 1 & $1982-1984^{b}$ & $117(38)^{\mathrm{c}}$ & $110(35)$ & $103(37)$ & $0 / 200$ & plasma $^{d} 10 \mu \mathrm{g}$ & $0,1,2,11$ \\
\hline II & $1982-1984$ & $121(42)$ & $109(37)$ & $105(41)$ & $0,3 / 200,125$ & plasma $10 \mu \mathrm{g}$ & $3,4,5,11$ \\
\hline III & $1984-1987^{\circ}$ & $133(3)$ & $128(2)$ & $127(3)$ & $0 / 200$ & plasma $10 \mu g$ & $0,1,6$ \\
\hline IV & $1984-1987$ & $124(4)$ & $122(4)$ & $115(2)$ & $0 / 200$ & plasma $5 \mu \mathrm{g}$ & $0,1,6$ \\
\hline v & $1988-1989$ & $112(14)$ & $102(13)$ & $98(14)$ & $0 / 300$ & recomb. $20 / 1 \mathrm{~g}$ & $3,4,5,11$ \\
\hline VI & $1988-1989$ & 98 (17) & $93(17)$ & $83(17)$ & $0,3 / 300,300$ & recomb. $20 \mu \mathrm{g}$ & $3,4,5,11$ \\
\hline Total & $1982-1989$ & $705(118)$ & $664(108)$ & $631(114)$ & & & \\
\hline
\end{tabular}

"Hepatitis B immunoglobulin, Central Laboratory of the Dutch Red Cross Blood Transfusion Service, The Netherlands; ${ }^{i}$ infants of HBeAg positive mothers entered in group I and II until December 1987; cbetween parentheses number of intants with HBeAg positive mothers; 'HBvax, Merck Sharp \& Dohme, Westpoint, USA; 'Engerix-B, SmithKline Beecham Biologicals, Rixensart, Belgium 
HBsAg, $\mathrm{HBeAg}$, anti-HBc and anti-HBs were assessed using a commercial radioimmunoassay kit (Abbott Laboratories, Chicago, IL, USA). HBV DNA was measured quantitatively by a solution hybridization assay (HBV DNA, Abbott Laboratories).

\section{Definition of HBV infection}

A HBV carrier state was defined as being HBsAg positive for more than 6 months. Transient HBV infection was characterized by the presence of $\mathrm{HBsAg}$ in serum for less than 6 months. Inapparent HBV infection was defined as anti-HBc positivity without $\mathrm{HBsAg}$ on two or more occasions after 12 months.

\section{Statistical analysis}

Available data were analysed according to the intention-to-treat principle. Separate per-protocol analysis, i.e. analysis of data of children who received vaccinations according to protocol, was also performed. The results of these analyses did not differ significantly. Therefore, the authors report on the protective efficacy using outcomes of the intention-to-treat analysis; the results on the immunogenicity are reported using the outcomes of the per-protocol analysis.

For analysis of factors affecting the protective efficacy rate, logistic regression analysis ${ }^{\mathrm{x}}$ was applied. Confidence limits for odds ratio were calculated using the statistical software package 'STATXACT'. Differences in percentages were analysed by $\chi^{2}$ test or Fisher's exact test in case of small numbers. Continuous variables were analysed by the two-sample Wilcoxon rank-sum test. The limit for significance was set to 0.05 (two-sided). In case of evaluations at various timepoints, the limit of significance was set according to Bonferroni's principle to allow for the multiplicity of statistical tests. Geometric mean titers (GMT) were calculated only for those infants who had anti-HBs $\geq 10 \mathrm{IU} \mathrm{I}^{-1}$.

\section{Ethics}

The study was approved by the local Medical Ethics Committee of the participating centers.

\section{RESULTS}

\section{Follow-up}

From July 1982 until October 1989, 705 infants of HBsAg-positive mothers were randomized into three controlled trials. Sixteen infants were withdrawn after informed consent but before vaccination, 12 infants received at least one vaccination, but no serum sample was available after month 0 . In total, 677 infants received full courses of passive-active immunization according to six schedules (Table 1). Thirteen infants received vaccinations but not according to protocol (one in group I, four in group II, one in group III, one in group IV, three in group $\mathrm{V}$ and three in group VI). Thus, 664 infants received passive-active immunization according to protocol. Serum samples were available from 590 children at 1 year of follow-up, 546 after 2 years, 262 after 5 years and 126 after 8 years. Incomplete data from these children were primarily due to secondary refusal of the parents, related to the frequency of blood sampling (up to ten samples) during the study, and migration.

\section{Protective efficacy of perinatal HBV immunization}

At month 12, $\mathrm{HBsAg}$ positivity was found in eight of 590 infants. Of 33 infants no serum sample was available at month 12 but they were HBsAg negative thereafter, so the assumption was made that there was no HBsAg positivity at month 12 . From eight of the 13 infants who received a vaccination schedule not according to protocol, serum samples were available and found to be HBsAg negative at month 12 or thereafter. Of 631 (i.e. $590+33+8$ ) infants analysed, eight (1.3\%) were found to be HBsAg-positive during the first year of life. All HBsAg-positive children were born to $\mathrm{HBeAg}$-positive mothers.

One infant of a $\mathrm{HBcAg}$-negative mother became HBsAg positive at the age of 5 years (Figure l); it had a peak anti-HBs level between 10 and 100 IU I' after vaccination, but was anti-HBs negative from 2 years onwards. This child and all infants found to be HBsAgpositive in the first year became hepatitis B carriers.

Inapparent $\mathrm{HBV}$ infection (anti-HBc positivity with negative $\mathrm{HBsAg}$ tests on two or more occasions after month 12) was observed in eight infants, all born to $\mathrm{HBe} A g$-positive mothers.

At month 12, the protective efficacy rate (PER) of passive-active immunization for the 114 infants of HBsAg- and $\mathrm{HBcAg-positive} \mathrm{mothers} \mathrm{was} 90 \%$ (Table 2). No significant differences were found between the PER for infants starting active vaccination at birth and those starting at 3 months; hetween infants starting at 3 months and receiving one or two doses of HBIg and between infants receiving plasma vaccine or recombinant vaccinc.

In 72 of the $114 \mathrm{HBcAg}$-positive mothers, residual frozen serum was available for quantitative HBV DNA assessment in 1992. Table 3 shows the relation of maternal HBV DNA levels and the number of infants who became HBV carricrs. The PER at month 12 for the two groups with HBV DNA levels $<150 \mathrm{pg} \mathrm{ml}$ were $100 \%$ and significantly higher than the PER $(68 \%)$ for the group with maternal HBV DNA levels $\geq 150 \mathrm{pg} \mathrm{ml} '(P=0.009)$.

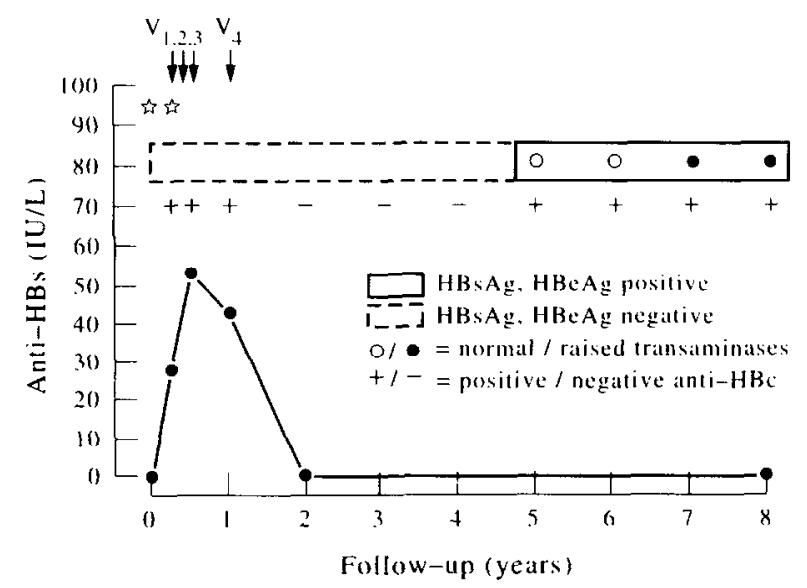

Figure 1 Chronic HBV infection after 5 years of follow-up in one infant, born to an HBeAg-negative mother, despite a response to neonatal passive-active hepatitis B immunization (group II) 
Table 2 Protective efficacy of passive-active hepatitis B immunization, at month 12 in infants of HBeAg-positive mothers, according to different vaccination schedules

\begin{tabular}{|c|c|c|c|c|c|}
\hline \multirow[b]{4}{*}{ Group } & \multirow{2}{*}{\multicolumn{2}{|c|}{ No. of infants }} & \multirow{4}{*}{$\begin{array}{l}\text { HBsAg positivity } \\
\text { difference in \% (95\% Cl) }\end{array}$} & \multicolumn{2}{|c|}{ PER $^{12 \text { months a }}(\%)$} \\
\hline & & & & \multirow{2}{*}{\multicolumn{2}{|c|}{$\begin{array}{l}\text { Expected \% of infants with } \mathrm{HBV} \\
\text { infections without prophylaxis }\end{array}$}} \\
\hline & \multirow[b]{2}{*}{ Total } & \multirow{2}{*}{$\begin{array}{l}\text { HBsAg } \\
\text { positive (\%) }\end{array}$} & & & \\
\hline & & & & $90 \%$ & $67 \%^{b}$ \\
\hline Vaccine starting month 0 & 42 & $3(7.1)$ & $0.2(-9.5,+9.9)$ & 92 & 89 \\
\hline Vaccine starting month 3 & 72 & $5(6.9)$ & & 92 & 90 \\
\hline HBIg month 0 & 56 & $4(7.1)$ & $0.2(-9.2,+9.2)$ & 92 & 89 \\
\hline HBlg months 0,3 & 58 & $4(6.9)$ & & 92 & 90 \\
\hline Plasma vaccine & 83 & $6(7,2)$ & $0.7(-9.6,+11.0)$ & 92 & 89 \\
\hline Recombinant vaccine & 31 & $2(6.5)$ & & 93 & 90 \\
\hline Total & 114 & $8(7.0)$ & & 92 & 90 \\
\hline
\end{tabular}

${ }^{\text {a }} \mathrm{PER}=$ (expected number of $\mathrm{HBV}$ infections without immunoprophylaxis minus measured number of HBV infections in immunization group) divided by the expected number of HBV infections without immunoprophylaxis) $\times 100 \%$; ${ }^{b}$ the expected number of HBV infections without immunoprophylaxis for infants from HBeAg positive mothers is usually estimated at $90 \%{ }^{21,22}$, however, PER was also calculated for $67 \%$ expected $\mathrm{HBV}$ infections without immunoprophylaxis, in view of the finding that one-third of infants of HBeAg-positive mothers had HBV DNA $<5 \mathrm{pg} \mathrm{ml}^{-1}$ and are therefore unlikely to transmit hepatitis $B$ to their infants ${ }^{6}$

Figure 2 shows the maternal HBV DNA levels for HBV infected infants and non-infected infants. The median maternal HBV DNA level of the HBV carrier infants and that of the inapparently infected infants werc ten times higher $\left(\approx 350 \mathrm{pg} \mathrm{m}^{-1}\right)$ than the median maternal HBV DNA level (31 $\left.\mathrm{pg} \mathrm{m}^{-1}\right)$ of the infants without HBV infection $(P=0.001$ and 0.03 , respectively).

When data on time of starting active vaccination, number of doses of $\mathrm{HBIg}$ and type of vaccine were analysed by multivariate logistic regression, no significant differences were found (odds ratio confidence intervals were from 0.001 to $>10$ ). When the analysis was expanded with HBV DNA data, both the factor HBV DNA as well as HBV DNA $>150 \mathrm{pg} \mathrm{ml}^{-1}$ were significantly associated with the PER.

\section{Long-term immunogenicity}

Assuming a minimal risk for hepatitis $B$ infection in vaccinees with anti-HBs levels $>10 \mathrm{IU} \mathrm{l}^{-1}$, and a potential risk with anti-HBs levels $<10 \mathrm{IU}^{-1}$, the authors calculated the percentages of infants with antiHBs $<10 \mathrm{IU}^{-1}$ in the different immunization groups (Figure 3). At the age of 5 ycars, the group that started at 3 months of age with plasma vaccine (group II) had a significantly lower percentage $(2 \%, 95 \% \mathrm{CI} 0-6 \%)$ of children with anti-HBs $<10 \mathrm{IU} \mathrm{I}^{\prime \prime}$ than group I $(14 \%$, 95\% CI 6-23\%) that started immunization at birth (Fisher's exact test, $P=0.02$ ). The percentage of infants with anti-HBs $<10 \mathrm{IU} l^{-1}$ in group II never exceeded $5 \%$ during the 5 year follow-up, whereas the corresponding percentage in the other immunization groups increased to $>15 \%$ during follow-up.

Table 4 shows the GMT of anti-HBs (anti-HBs $\left.\geq 10 \mathrm{IU} \mathrm{I}^{-1}\right)$ in the different immunization groups during follow-up. GMT of group II $(10 \mu \mathrm{g}$ plasma vaccine administration from 3 months of age onwards) was approximately double that of group I (starting at birth with $10 \mu \mathrm{g}$ plasma vaccine). In the groups with different dosages of vaccine, the GMT at month 12 in group III with three doses of $10 \mu \mathrm{g}$ plasma vaccine administered from birth onwards, was approximately double that of group IV, which received the same schedule but only $5 \mu \mathrm{g}$ of plasma vaccine. However, this difference was not significant after 36 months of follow-up. Comparison of GMT values of groups given plasma vaccine or recombinant vaccine from 3 months onwards showed that the group receiving plasma vaccine (group II) had an approximately one and half times higher GMT than the corresponding group receiving recombinant vaccine (group VI) $(P<0.001$ at all times measured).

\section{DISCUSSION}

In this meta-analysis of individual paticnt data of three randomized controlled trials, the PER against hepatitis $\mathrm{B}$ infection for infants of $\mathrm{HBeAg}$-positive carrier mothers was $90 \%$ at 12 months of age; for infants of HBeAg-negative mothers it was $100 \%$. These rates are comparable to those found in other passive-active immunization studies, with either plasma-derived or recombinant vaccine ${ }^{2-13}$. During follow-up beyond 1

Table 3 Protective efficacy rate (PER) of passive-active hepatitis B immunization at month 12 according to maternal HBV DNA levels

\begin{tabular}{|c|c|c|c|c|}
\hline \multirow[b]{2}{*}{ HBV DNA (pg ml $\left.{ }^{1}\right)$} & \multicolumn{2}{|c|}{ No. of infants } & \multirow{2}{*}{$\begin{array}{l}\text { PER }^{12 \text { months }} \\
90 \%\end{array}$} & \multirow[b]{2}{*}{$P$-value } \\
\hline & Total & HBsAg positive(\%) & & \\
\hline $\begin{array}{l}<6 \\
7-150 \\
>150\end{array}$ & $\begin{array}{l}24 \\
24 \\
24\end{array}$ & $\begin{array}{l}O(0) \\
O(0) \\
7(29)\end{array}$ & $\begin{array}{c}\text { n.a. }{ }^{a} \\
100 \\
68\end{array}$ & $0.009^{\star}$ \\
\hline
\end{tabular}

^Fisher's exact test between number of HBsAg-positive infants in group with HBV DNA > $150 \mathrm{pg} \mathrm{ml}^{-1}$ and groups with HBV DNA of 7-150 and $<6 \mathrm{pg} \mathrm{ml}^{-*}$; owing to small numbers of infants, the exact $95 \% \mathrm{Cl}$ of the ratio of the odds of $\mathrm{HBsAg}$ positivity in the group of infants with HBV DNA $<150 \mathrm{pg} \mathrm{ml}^{-1}$ (odds $0 / 48$ ) versus the corresponding odds $(7 / 24)$ in the group with HBV DNA $>150 \mathrm{pg} \mathrm{ml}^{-1}$ was calculated (this $95 \% \mathrm{Cl}$ ranged from 0 to 0.22 ); ${ }^{a}$ not applicable, in view of the finding that infants of HBeAg-positive mothers with $\mathrm{HBV}^{\mathrm{DNA}}<5 \mathrm{pg} \mathrm{ml}{ }^{-1}$ are unlikely to transmit hepatitis $B$ to their infants ${ }^{8}$ 
year, extending to 9 years, one vaccinated infant of an $\mathrm{HBeAg}$-negative mother became positive for $\mathrm{HBsAg}$.

The timing of the initial vaccine injection, the type of the vaccine and the number of doses of $\mathrm{HBIg}$ had no effect on the PERs. These results confirm earlier findings. Beasley et al. ${ }^{9}$. reported that, with $\mathrm{HBIg}$

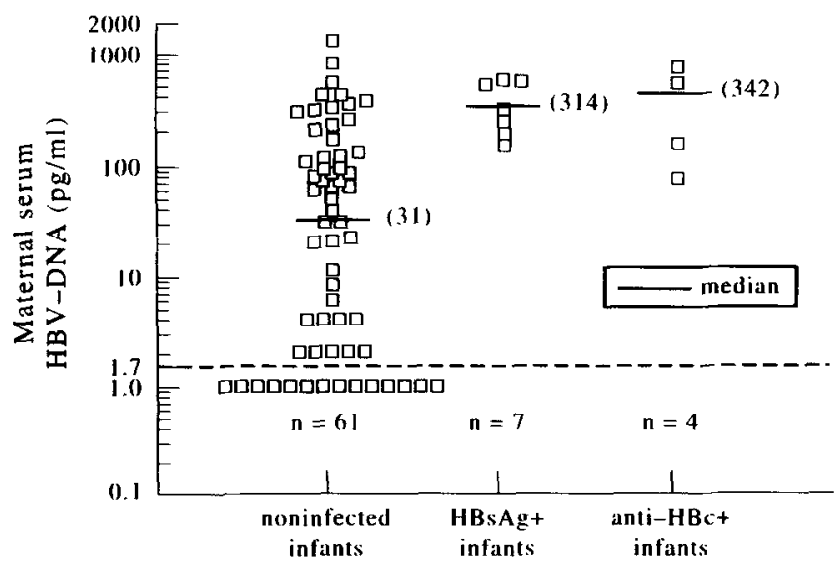

Figure 2 Maternal HBV DNA levels of seven chronic HBV infected infants, four inapparent HBV infected infants and of 61 non-infected infants. Cut-off level of HBV DNA assay is $1.7 \mathrm{pg} \mathrm{ml}^{-1}$

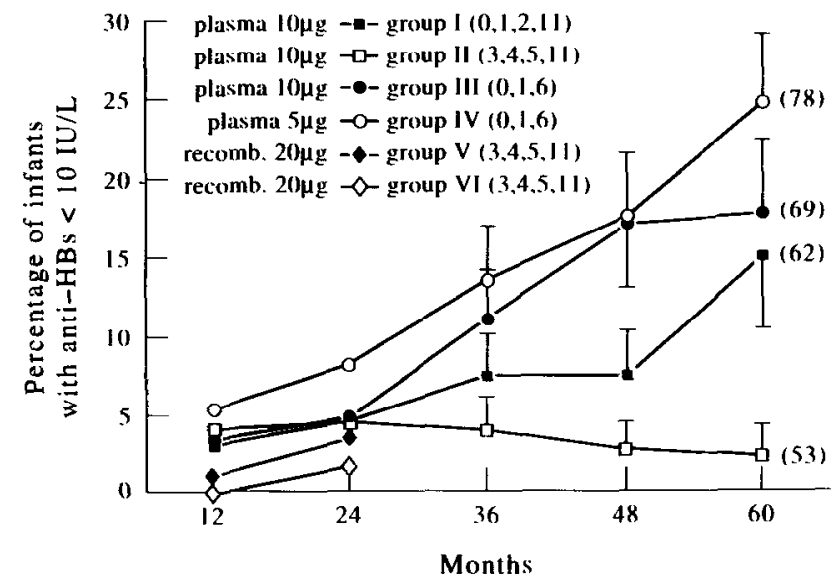

Figure 3 Percentages of infants with anti-HBs $<10|\mathrm{IU}|^{-1}$ in the six immunization groups. Bars indicate standard errors. Results at 2 years are similar for groups starting vaccination at birth or at 3 months of age. Long-term follow-up suggests excellent persistence of protective humoral immunity for infants starting vaccination at 3 months of age coverage at birth, the timing of the start of active vaccination appeared to be of no importance. A retrospective analysis by Marian et al. ${ }^{14}$ suggested lower efficacy for those receiving delayed vaccination; this finding, however, relates to compliance rather than to the biology of immune protection. Stevens et al. ${ }^{12}$ published results indicating that yeast recombinant vaccine was as effective as plasma-derived vaccine in preventing hepatitis $B$ virus infection. The authors of this study found no evidence of a need for a second dose of HBIg in combination with delayed active immunization; evidence from other studies for the necessity of such action has not been forthcoming.

In the setting of our program, with the use of licensed vaccine and adequate dosage of $\mathrm{HBIg}$, the single clinically relevant factor that did influence the PER was the level of serum HBV DNA of the mother at the time of delivery. PER in groups of infants with maternal HBV DNA levels $<150 \mathrm{pg} \mathrm{ml}^{-1}$ was $100 \%$, but only $68 \%$ for the group with a maternal HBV DNA level of $\geq 150 \mathrm{pg} \mathrm{ml}^{-1}$.

To verify the finding that PER is markedly influenced by maternal HBV DNA levels, the authors analysed the protective efficacy rate at 12 months of age according to quantified maternal HBV DNA levels from the neonatal hepatitis $B$ vaccination program in Hong Kong ( 6 , P.N. Lelie, written communication). In the Hong Kong study, no persistent HBsAg positivity at 12 months was detected in infants with maternal HBV DNA $<5 \mathrm{pg} \mathrm{ml}^{-1}$, irrespective of immunization schedule. Infants with maternal HBV DNA between 7 and $150 \mathrm{pg} \mathrm{ml}^{-1}$ were at risk of hepatitis $B$ infection (15-28\% HBsAg carrier rate). Infants with maternal HBV DNA levels of $>150 \mathrm{pg} \mathrm{ml}^{-1}$ were at high risk of hepatitis $\mathrm{B} ; 25-50 \%$ of infants became persistent HBsAg positive despite immunization. These results strongly support the concept that the level of maternal HBV DNA is the major factor influencing the PER of hepatitis B immunization.

Recently, hepatitis B 'escape mutants', lacking the ' $a$ ' epitope on the viral envelope were found in vaccinated infants ${ }^{15}$. The authors did not observe coexistence of $\mathrm{HBsAg}$ and anti-HBs in seven infants with persistent HBsAg. However, additional laboratory investigations including in vitro neutralization of HBsAg by polyclonal anti-HBs (HBIg, CLB) and sequence analysis of the ' $a$ ' domain revealed one arginine 145 variant in three cases that were available for investigation. 'Escape' mutants may also play a role

Table 4 GMT anti-HBs (anti-HBs $\geq 10 / \mathrm{UI}^{-1}$ ) in the six immunization groups during follow-up. Values in parentheses are the $95 \% \mathrm{Cl}$

\begin{tabular}{|c|c|c|c|c|c|}
\hline \multirow[b]{2}{*}{ Group } & \multicolumn{5}{|l|}{ GMT anti-HBs (IU I ' $)$} \\
\hline & Month 12 & Month 24 & Month 36 & Month 48 & Month 60 \\
\hline $\begin{array}{l}(0,1,2,11 ; 10 \mu \mathrm{g} \text { pl. }) \\
\text { II }(3,4,5,11 ; 10 \mu \mathrm{g} \mathrm{pl}) \\
P \text {-value }\end{array}$ & $\begin{array}{l}8730(6238-12217) \\
15739(11738-21104) \\
0.023\end{array}$ & $\begin{array}{l}737(533-1019) \\
1728(1284-2325) \\
0.001\end{array}$ & $\begin{array}{l}353(248-502) \\
820(596-1129) \\
0.0006\end{array}$ & $\begin{array}{l}207(145-296) \\
484(356-231) \\
0.0004\end{array}$ & $\begin{array}{l}137(92-203) \\
331(231-473) \\
0.0002\end{array}$ \\
\hline $\begin{array}{l}<\text { vsp sp = "0.5" } \\
\text { III }(0,1,6 ; 10 \mu \mathrm{g} \mathrm{pl}) \\
\text { IV }(0,1,6 ; 5 \mu \mathrm{g} \mathrm{pl} .) \\
P \text {-value }\end{array}$ & $\begin{array}{l}1142(849-1537) \\
608(438-846) \\
0.0012\end{array}$ & $\begin{array}{l}331(245-447) \\
203(146-283) \\
0.0066\end{array}$ & $\begin{array}{l}202(151-271) \\
163(116-228) \\
0.19\end{array}$ & $\begin{array}{l}138(100-90) \\
114(78-166) \\
0.31\end{array}$ & $\begin{array}{l}100(70-143) \\
75(52-109) \\
0.11\end{array}$ \\
\hline $\begin{array}{l}<\text { vsp sp }=" 0.5^{\prime \prime} \\
\text { V }(3,4,5,11 ; 20 \mu \mathrm{g} \text { rec.) } \\
\text { VI }(3,4,5,11 ; 20 \mu \mathrm{g} \text { rec.) } \\
P \text {-value }\end{array}$ & $\begin{array}{l}9317(6558-13237) \\
9699(6475-14528) \\
0.13\end{array}$ & $\begin{array}{l}1727(1216-2452) \\
1125(767-1649) \\
0.84\end{array}$ & - & $\begin{array}{l}- \\
-\end{array}$ & $\begin{array}{l}- \\
-\end{array}$ \\
\hline
\end{tabular}

${ }^{a}$ Between groups I and II; ${ }^{b}$ between groups III and IV; 'between groups V and VI 
in a low-endemic region like northwestern Europe, but the extent of the problem appears limited.

Long-term immunogenicity was significantly higher in the group receiving late active immunization than in the group starting directly after birth. At the age of 5 years, the group with delayed active immunization had a significantly lower percentage $(2 \%)$ of children with anti-HBs $<10 \mathrm{IU} \mathrm{I}^{-1}$ than groups in which immunization was started at birth (15-25\%). This finding is in agreement with others who found an enhancement of the immune response if the infant was older at the time of the initial injection, probably related to a more mature immune system ${ }^{14.16}$. The implications of these findings are at present unclear. If protection against hepatitis B infection depends on the degree of immunologic priming reflected by the persistence of antibody, then a strong argument could be made for adoption of schedules that maximize anti-HBs levels. In the present study, there was a total follow-up of 186 person-years in 71 infants with anti-HBs <10 IUI! One infant, born to a HBeAg-negative mother, with an initial response between 10 and $100 \mathrm{IU} \mathrm{I}^{-1}$ became HBsAg carrier after 4 years of follow-up without detectable anti-HBs. In other studies, no HBsAg positivity after 5-9 years of follow-up was found for infants with initial anti-HBs $\geq 10 \mathrm{IU} \mathrm{I}^{-1}$, whether the infants lost their anti-HBs or not ${ }^{14,16-18}$. In long-term follow-up studies of immunized adults, no persistent HBsAg positivity was detected in persons with an initial anti-HBs response $>10$ SRU, but transient HBsAg positivity and/or anti-HBc positivity was detected in this group, $<1 \%$ in 100 person-years exposed $^{19}$. At present, until more long-term follow-up studies are available, it seems advisable to aim for an initial anti-HBs response of $100 \mathrm{IU} \mathrm{I}^{-1}$ or more for the prevention of clinically important forms of hepatitis $\mathrm{B}^{20}$.

The confirmation of an old finding that there was no effect of the time of starting active immunization on PER facilitates the incorporation of hepatitis B vaccine into the existing Expanded Programme on Immunization (EPI) by allowing active hepatitis B vaccination concomitant with DKTP immunization. The number of visits can then be reduced as well as the number of injections if a multivalent vaccine becomes available.

\section{ACKNOWLEDGEMENTS}

The following participants of the Dutch study group Prevention Neonatal Hepatitis B are acknowledged for their contribution: J.W. Wladimiroff, Department of Obstetrics, Academic Hospital Dijkzigt, Rotterdam; A.S.M. Nuijten, State School of Training for Obstetricians, Rotterdam; J.R.J. Bänffer, Regional Public Health Laboratory, Rotterdam; M.J. Botman, Regional Laboratory of Pathology and Microbiology, Enschede; G.C.M.L. Christiaens, Department of Gynaecology and Obstetrics, Academic Hospital, Utrecht; W. Baerts, Department of Pediatrics, St. Sophia Hospital, Zwolle. The study group is grateful to the Steering Committee formed by Professor Dr J. Huisman, Professor Dr J.W. Stoop, Dr H. Bijkerk and the late Professor S. Krugman. The authors are grateful to M. Bakker-
Bendik, Th. van der Laar-Kokx, H. Ribbers-Smeenk, H.C. van Dijk and M. Voogd-Schotanus for their outstanding help in this study for several years. Special thanks go to Y.A.M. Weber, J. Kruining and H.G.M. Niesters for performing the laboratory tests; J. Boot for technical assistance; P.N. Lelie for making available the maternal HBV DNA assays of the Hong Kong neonatal hepatitis B vaccination program; and B.E. Hansen for performing multivariate analysis. This stuy was supported by a grant from the Praeventiefonds, Netherlands (no. 28-760)-2).

\section{REFERENCES}

1 Mazel, J.A., Schalm, S.W., de Gast, B.C., Nuijten, A.S.M. Heijtink, R.A., Botman, M.J., Bänffer, J.R.J., Gerards, L.J., Zwijnenberg, J., Mettau, J., Wladimiroff, Y.W. and Fetter, W.P.F. Passive--active immunisation of neonates of $\mathrm{HBsAg}$ positive carrier mothers: preliminary observations. British Medical Journal 1984, 288, 513-515.

2 Schalm, S.W., Mazel, J.A., de Gast, G.C., Heijtink, R.A., Botman, M.J. and Bänffer, J.R.J. et al. Prevention of hepatitis $B$ infection in newborns through mass screening and delayed vaccination of all infants of mothers with hepatitis $B$ surface antigen. Pediatrics 1989, 83, 1041-1048.

3 Grosheide, P.M., del Canho, R., Voogd, M., Heijtink, R.A. Schalm, S.W. and Dutch Study Group Prevention Neonatal Hepatitis B, Anti-HBs levels in infants of hepatitis B carrier mothers after delayed active immunization with recombinant vaccine concomitant with DTP-Polio vaccine: Is there need for a second dose of HBlg? Vaccine 1994, 12, 1059-1063.

4 del Canho, R., Grosheide, P.M., Schalm, S.W., de Vries, R.R.P. and Heijtink, R.A. Failure of neonatal hepatitis $B$ vaccination: The role of HBV DNA levels in hepatitis $B$ carrier mothers and HLA antigens in neonates. Journal of Hepatology 1994, 20, 483-486

5 Lee, S.D., Lo, K.J., Wu, J.C., Tsai, Y.T., Wang, J.Y. and Ting L.P. et al. Prevention of maternal-infant hepatitis $B$ virus trans mission by immunization: The role of serum hepatitis $B$ virus DNA. Hepatology 1986, 6, 369-373.

6 Ip, H.M.H., Lelie, P.N., Wong, V.C.W., Kuhns, M.C. and Reesink, H.W. Prevention of hepatitis $B$ virus carrier state in infants according to maternal serum levels of HBV DNA Lancet 1989, i, 406-410.

7 Lin, H.H., Chang, M.H., Chen, D.S., Sung, J.L., Hong, K.H. and Young, Y.C. et al. Early predictor of the efficacy of immunoprophylaxis against perinatal hepatitis $B$ transmission: analysis of prophylaxis failure. Vaccine 1991, 9, 457-460.

8 Altman, D.G. Practical Statistics for Medical Research Chapman and Hall, London, 1995, pp. 351-358.

9 Beasley, R.P., Hwang, L.Y., Lee, G.C., Lan, C., Roan, C. and Huang, F. et al. Prevention of perinatally transmitted hepatitis $B$ virus infections with hepatitis $B$ immune globulin and hepatitis B vaccine. Lancet 1983, ii, 1099-1102.

10 Wong, V.C.W., Ip, H.M.H., Reesink, H.W., Lelie, P.N., ReerinkBrongers, E.E. and Yeung, C.Y. et al. Prevention of the HBsAg carrier state in newborn infants of mothers who are chronic carriers of $\mathrm{HBsAg}$ and $\mathrm{HBeAg}$ by administration of hepatitis $B$ vaccine and hepatitis $B$ immunoglobulin. Lancet 1984, i, 921-926.

11 Coursaget, P., Yvonnet, B., Chotard, J., Sarr, M., Vincelot, P. and N'doye, R. et al. Seven-year study of hepatitis B vaccine efficacy in infants from an endemic area (Senegal). Lancet 1986, ii, $1143-1145$

12 Stevens, C.E., Taylor, P.E., Jong, M.J., Toy, P.T., Vyas, G.N. and Nair, P.V. et al. Yeast-recombinant hepatitis $B$ vaccine: Efficacy with hepatitis $B$ immune globulin in prevention of perinatal hepatitis $\mathrm{B}$ virus transmission. JAMA 1987, 257, 2612-2616.

13 Poovorawan, Y., Sanpavat, S., Pongpuniert, W., Chumdermpadetsuk, S., Sentrakul, P. and Safary, A. Protective efficacy of a recombinant DNA hepatitis $B$ vaccine in neonates of $\mathrm{HBe}$ antigen-positive mothers. JAMA 1989, 261, 3278-3281.

14 Marion, S.A., Tomm Pastore, M., Pi, D.W. and Mathias, R.G. Long-term follow-up of hepatitis $B$ vaccine in infants of carrier 
Efficacy and immunogenicity neonatal hepatitis $B$ vaccination: $R$. del Canho et al.

mothers. American Journal of Epidemiology 1994, 140, 734-746.

15 Carman, W.F., Zanetti, A.R., Karayiannis, P., Waters, J., Manzillo, G. and Tanzi, E. et al. Vaccine-induced escape mutant of hepatitis B virus. Lancet 1990, 336, 325-329.

16 Stevens, C.E., Toy, P.T., Taylor, P.E., Lee, T. and Yip, H.Y. Prospects for control of hepatitis B virus infection: implications of childhood vaccination and long-term protection. Pediatrics 1992, 90, 170-173.

17 Lieming, D., Mintai, Z., Yinfu, W., Shaochon, Z., Weiqin, K. and Smego, R.A. A 9-year follow-up study of the immunogenicity and long-term efficacy of plasma-derived hepatitis B vaccine in high-risk Chinese neonates. Clin. Inf. Dis. 1993, $17,475-479$

18 Lo, K.J., Lee, S.D., Tsai, Y.T., Wu, T.C., Chan, C.Y. and Chen, G.H. et al. Long-term immunogenicity and efficacy of hepatitis
$B$ vaccine in infants born to $\mathrm{HBeAg}$-positive $\mathrm{HBs} A g$-carrier mothers. Hepatology 1988, 8, 1647-1650.

19 Hadler, S.C., Francis, D.P., James, D.S., Maynard, J.E., Thompson, S.E. and Judson, F.N. et al. Long-term immunogenicity and efficacy of hepatitis $B$ vaccine in homosexual men. New England Journal of Medicine 1986, 315, 209-214.

20 Workshop Report, Immunisation against hepatitis B. Lancet $1988,1,875-876$

21 Okada, K., Kamiyama, I., Inomata, M., Imai, M., Miyakawa, Y. and Mayumi, $M$. e antigen and anti-e in the serum of asymptomatic carrier mothers as indicators of positive and negative transmission of hepatitis B virus to their infants. New England Joumal of Medicine 1976, 294, 746-749.

22 Beasley, R.P. and Hwang, L.Y. Postnatal infectivity of hepatitis B surface antigen-carrier mothers. Journal of Infectious Diseases 1983, 147, 185-190. 